This item was submitted to Loughborough's Research Repository by the author.

Items in Figshare are protected by copyright, with all rights reserved, unless otherwise indicated.

\title{
New frontiers of studentification: the commodification of student housing as a driver of urban change
}

PLEASE CITE THE PUBLISHED VERSION

https://doi.org/10.1111/geoj.12263

\section{PUBLISHER}

(C) Royal Geographical Society (with the Institute of British Geographers). Published by Wiley

\section{VERSION}

AM (Accepted Manuscript)

\section{PUBLISHER STATEMENT}

This is the peer reviewed version of the following article: KINTON, C. ... et al, 2018. New frontiers of studentification: the commodification of student housing as a driver of urban change. The Geographical Journal, 184(3), pp. 242-254, which has been published in final form at https://doi.org/10.1111/geoj.12263. This article may be used for non-commercial purposes in accordance with Wiley Terms and Conditions for Use of Self-Archived Versions.

\section{LICENCE}

CC BY-NC-ND 4.0

\section{REPOSITORY RECORD}

Kinton, Chloe, Darren Smith, John Harrison, and Andreas Culora. 2018. "New Frontiers of Studentification: The Commodification of Student Housing as a Driver of Urban Change". figshare. https://hdl.handle.net/2134/33456. 


\title{
NEW FRONTIERS OF STUDENTIFICATION: THE COMMODIFICATION OF STUDENT HOUSING AS A DRIVER OF URBAN CHANGE
}

\author{
Chloe Kinton* / Darren P Smith / John Harrison / Andreas Culora \\ Department of Geography \\ School of Social, Political and Geographical Sciences \\ Loughborough University \\ Loughborough \\ United Kingdom \\ LE11 3TU \\ $+44(0) 1509222791$ \\ c.kinton2@lboro.ac.uk / d.p.smith@lboro.ac.uk / j.harrison4@lboro.ac.uk / \\ a.culora@lboro.ac.uk \\ ${ }^{*}$ Author for correspondence
}

Accepted version of paper appearing in The Geographical Journal 


\section{ABSTRACT}

Studentification has permeated policy-orientated agendas on community cohesion in different national contexts, and is of increasing public relevance at a time of changing systems of higher education. To date, studentification has been treated as a process of urban change that leads to the physical downgrading of neighbourhoods and social conflict, tied to concentrations of low-quality student houses in multiple occupation (HMOs). Our aim in this paper is to widen conceptual understandings of studentification, drawing upon a novel study of this process in Loughborough, UK. Focussing on the Kingfisher estate, we provide the first investigation of the formation of a studentified neighbourhood, using data from administrative datasets to track tenurial transformations from owner-occupation to private rental shared housing. Our analyses are deepened from a survey of student preferences for accommodation, and interviews with local community representatives, to reveal a productionconsumption interface for high-quality student housing in Kingfisher. We argue that this is illustrative of a new frontier of studentification, which emphasises the volatility of student housing markets. Crucially, these dynamics are having a significant influence on broader changing urban geographies, such as the de-studentification of other neighbourhoods, and the overall supply of (affordable) housing. Our paper concludes by arguing for a wider conceptualisation of studentification that does not inherently view the process as a harbinger of downgraded urban environments. From a policy perspective, our research stresses the urgent need for different place-specific solutions and policy interventions to mitigate the challenges of studentification.

Key words: studentification; de-studentification; urban policy; housing affordability; urban change 


\section{NEW FRONTIERS OF STUDENTIFICATION: THE COMMODIFICATION OF STUDENT HOUSING AS A DRIVER OF URBAN CHANGE}

\section{INTRODUCTION}

Studentification is a significant process of urban change, tied to growing concentrations of university students, that has widely penetrated national public debates and policy-orientated agendas during the last two decades (Nakazawa, 2017; Moos et al., 2018). As a highlycontentious societal and economic issue (He, 2015; Holton, 2016), studentification is often represented in negative ways in pejorative media discourses across the globe, including Australia (Ruming and Dowling, 2017), China (Zhao and Zou, 2017), Hungary (Fabula et al., 2017), Malaysia (Ghani and Suleiman, 2017), South Africa (Ackermann and Visser, 2016), Spain (Garmendia et al., 2012) and the USA (Foote, 2017).

Studentification is predominantly treated as a phenomenon that gives rise to conflictual social relations between settled and student populations, downgraded physical environments, and detrimental effects on local housing markets (Munro and Livingstone, 2011). It is a process of urban change that is fuelled by market forces that create geographies of low-quality, high-density, student houses in multiple occupation (HMOs), usually near a university campus. This is underpinned by normative practices of co-residence in off-campus, 'shoddy' private-rented housing being "an integral component of the student habitus" (Smith and Holt, 2007: 152). As Chatterton (2010: 509) emphasises: 
"I am reminded by a friend that student accommodation is referred to as digs as it reflected the fact that students used to ... spend a few years at university tolerating substandard accommodation in a subterranean world, looking forward to a brighter future".

Recently, these relationships have been disrupted by the commodification of studenthood, leading to increasing demand for and supply of high-cost and high-quality accommodation built for students (Holton and Riley, 2016). This involves the development and management of large blocks of purpose-built student accommodation (PBSA) by commercial providers, and reinforces how processes of studentification have a transformative effect on both established residential neighbourhoods and the regeneration of vacant brownfield and other sites, across a wide range of locations. Moreover, the rise of PBSA points to universities increasingly becoming more disengaged in the student housing market, as the provision, management and maintenance of student accommodation is ceded to increasingly powerful commercial organisations. In this way, studentification is a major process of contemporary urban change that is reshaping broader urban geographies.

Within this context, our main aim in this paper is to deepen knowledge of the production and consumption of relatively high-quality and high-cost $\mathrm{HMO}$. This is an emerging geographical dimension of studentification that is tied to the ongoing commodification of studenthood, and begs key questions about the salience of dominant conceptualisations of studentification which are, arguably, narrow and need to be extended to incorporate more diverse forms of student housing. This is important at a time when traditional forms of student HMOs are increasingly restricted and regulated. Nowhere is this more evident than in the UK following the introduction of national legislation such as Article 4 Directions (now 
requiring planning permission for the conversion of a family dwelling (C3) to a $\mathrm{HMO}$ (C4) with three or more unrelated people living together).

To achieve this the paper is divided into five parts. Section two critically reviews scholarship on the 'commodification of studenthood'. In Section three, we draw upon findings from a study of studentification in Loughborough, UK, to track the transformation of housing in Kingfisher estate from new-build family dwellings to student $\mathrm{HMO}$. In the fourth section we analyse findings from a survey of student accommodation preferences and expectations for facilities and amenities, and the influence of rental costs. The final section reveals the important wider implications of the formation of new frontiers of studentification on broader urban geographies, highlighting four key areas of urban change pivotal to shaping a (re)new(ed) research agenda.

\section{THE COMMODIFICATION OF STUDENT HOUSING AND NEW URBAN GEOGRAPHIES?}

From the mid-2000s there has been a growing recognition that students are key agents of change in towns and cities, with studies showing how students can act as triggers and consumers of urban regeneration, via consumption of new PBSA and commodified student lifestyles (Fincher and Shaw, 2009). Motivated by the need to mitigate the negative effects of studentification by integrating students more effectively into established residential neighbourhoods, many local authorities, in partnership with universities and other leading stakeholders (e.g. commercial developers and local community organisations), have strategically enabled and facilitated the development of off-campus PBSA (Smith, 2005, 2008). In tandem, there has also been the large-scale refurbishment of on-campus halls of residence that is interwoven with changing demands for student accommodation in PBSA (Sage et al., 2012a; 2012b; 2013; Smith and Hubbard, 2014). In part, this is tied to the growing 
internationalisation of higher education, and the assumption that international students predominantly seek high-quality PBSA and are steered into this form of accommodation by agents. This may also be driven by the desire by universities to capture conference trade and generate income from investment in accommodation and facilities in non-academic periods when the student population is absent.

This direction of travel is part of a broader changing relationship between student populations, consumerism, and neoliberalism. The marketisation of higher education (e.g. Brooks et al., 2016) has gained prominence in the UK following successive governments' attempts to shift the funding of higher education away from the state. The assumption behind such policies is that students will demand high-quality provision, and thereby apply pressure to universities to make courses more relevant. One result is that prospective students become consumers before they enter higher education: shopping around for the best value for money and encouraged by Government to be "more discerning" (DBIS, 2011: 29) when it comes to making their higher education choices. Related to this, it is assumed that the actions of student consumers will have a positive impact - low quality will be penalised and consumer choice will foster competition between universities resulting in more responsive and higher quality teaching. This, alongside competitive university league tables, the production of student charters, and ramifications of student debt under neoliberal capitalism, encapsulates the notion of higher education as a commodity.

As Brooks et al. (2016: 1213) reveal, the radical changes to higher education funding in England (allowing institutions to charge up to $£ 9,050$ per annum in tuition fees from 2012, f9250 from 2017), often mean that students "see a degree as a private investment (rather than a public good); [are] prepared to accumulate significant debt in order to acquire it; and actively "shop around"' for products, goods and services. This framing of "students-as- 
consumers' clearly extends beyond the selection of universities and courses into other aspects of university life - primarily having a bearing on the residential decision-making processes and expectations of students, and normative ideas about the quality and cost of student housing and student living. Indeed, contemporary students are viewed by many commercial organisations as more discerning consumers, prepared to take on higher levels of cost and financial debt for student lifestyles and housing.

As a result, there appears to be a growing trend of changing student geographies, with developments of PBSA attracting students away from traditional living pathways (e.g. university campus to shared, off-campus $\mathrm{HMO}$ ) and into "more niche and exclusive on-site facilities" (Holton and Riley, 2013: 64). For example, in Leeds, UK, Chatterton (2010) observes that urban transformations are tied to changing geographies of student housing, as illustrated by penthouses in PBSA being pre-let before completion. Similar developments are common in other towns and cities, such as the growth of high-quality student accommodation in Cork, Ireland, encouraged by government incentives (Kenna, 2011), and the exclusive gated-style living of developments such as Chapter Spitalfields in London where rooms cost between £265-£699 per week (Prodigy Living, 2016). Hubbard (2009: 1904) suggests that such developments illustrate how "studenthood is itself now being effectively gentrified", underpinned by "institutional investors identifying students as part of that group which possesses a 'metropolitan habitus' and is hence willing to pay a premium for inner-city living". This demonstrates how the student housing market is becoming more diverse. As Holton and Riley (2013: 64) contend, there is a need to conceptualise a new type of student - one which does not conform to the stereotypical, cash-restricted, student lifestyle, "opting instead for high-end, passive, modular living". 
Nevertheless, the notions about commodification of studenthood provide a useful conceptual framework for exploring student preferences and expectations. This manoeuvre is necessary given that "very little has been written about how students weigh up the merits of different forms of accommodation" (Hubbard 2009: 1912). Whilst there is a growing body of research exploring the commodification of studenthood and student lifestyles, this scholarship has tended to focus on PBSA (e.g. Chatterton, 2010). Limited attention, to date, has been given to the increasing commodification and supply of new forms of student HMO. This is the main focus of our paper which uses the case study of Loughborough in the East Midlands, UK.

\section{METHODOLOGY}

To examine changing geographies of studentification, we draw upon findings from a wider study of diverse and changing expressions of studentification in Loughborough (see Kinton et al., 2016). More specifically, in this paper we focus on tracking the tenurial transformation of housing in Kingfisher, a new-build housing estate within close proximity to the campus of Loughborough University. Using Loughborough University term-time address datasets we identify the first time when one or more student resident(s) are indicated within individual dwellings, and this is cross-referenced to individual property transactions using Land Registry datasets, alongside other datasets (Council Tax, Electoral Register) to identify the production of HMOs. It is therefore possible for us: (i) to construct a broad historical analysis from the initial development of the housing estate in 2001 to the present day; (ii) to undertake the first-ever longitudinal exploration of the formation of a studentified neighbourhood; and (iii) to provide indication of the production of HMOs. 
To explore further the connections between student residential decision-making practices, processes of (de-)studentification, and the ongoing trajectory of student geographies, a face-to-face student accommodation questionnaire survey with 269 first-year undergraduates was conducted in Loughborough University halls of residence. A random stratified sampling frame for the survey targeted specific halls of residence (on/off campus; catered/self-catered; newly-built/traditional) as well as by nationality (UK; EU; non-EU international) and gender (male; female) to reflect the student population and capture a 5\% sample. The survey was designed to capture both quantitative and qualitative data, and to establish and classify where students want to live, and the reasons why (with a specific focus on University halls of residence, traditional HMOs, newly-converted HMOs, and town-centre PBSA) - focussing on students' experiences and also their preferences and perceptions (with specific reference to quality, cost and location) of student accommodation in Loughborough. All responses were recorded on the survey sheets, fully transcribed and thematically coded. Quotations are used to highlight key points and are not representative of all views.

Finally, semi-structured interviews with relevant institutional actors (estate agents, private landlords and PBSA providers), including the representative of the Kingfisher Area Residents Group (KARG), took place in January 2017 to capture perceptions of urban change connected to the in-migration of the student populations into Kingfisher, and to shed light on the how the neighbourhood had been transformed by studentification.

\section{CHANGING GEOGRAPHIES OF STUDENTIFICATION IN LOUGHBOROUGH}

As Hubbard (2008) and Kinton et al. (2016) reveal, since the 1990s terraced student housing in Loughborough has been concentrated in Storer and Burleigh. This 'student area', often referred to as the 'Golden Triangle', was identified as one of the most studentified wards in 
the 2001 UK Census with 17\% of households inhabited by students (Hubbard, 2009). The typical signifiers of studentification engrained in the Golden Triangle, include: the closure of the local primary school due to the depopulation of families with children, relatively high levels of noise nuisance, burglaries, spillage of refuse and litter onto streets, unkempt gardens, fly-tipping of unwanted furniture and electrical goods, and lack of car parking (Kinton et al., 2016).

With the rapid production from the mid-2000s of both on- and off-campus PBSA - to meet a growing demand from students for higher-quality accommodation and encouraged by the local authority to mitigate the detrimental effects of studentification in the Golden Triangle - the supply-demand nexus in the Loughborough student housing market has been transformed. This has led to the on-going de-studentification (broadly defined as student population loss from a previously student-dominated area) of the Golden Triangle, typified by partial-occupancy or empty accommodation, reduced rental rates, devalued property prices, landlord withdrawal, deterioration of the urban environment, and the loss of viability/closure of student-oriented services (Kinton et al., 2016). In this paper, we focus on another important way that the local student housing market has been reoriented via the production of high-quality student $\mathrm{HMO}$ in another part of Loughborough town.

Comprising 214 new-build townhouse properties in a cul-de-sac setting (Figure 1), directly adjacent to Loughborough University's campus, the development of Kingfisher was originally marketed as 'executive homes' and sold to middle class families when completed in 2001. As one leading community representative revealed:

"When the houses were first built in 2001 my understanding is there was no planning legislation at that time that prevented houses being bought by private landlords 
basically. Initially there were quite a number of properties bought by ordinary residents, and I think in the early days some of those changed hands and were bought by landlords because they quickly realised that this was a prime location in terms of access to the university. The estate is $75-80 \%$ student now and it's $95 \%$ student on Goldfinch Close" [Interview, Kingfisher resident].

Analysis of our novel dataset of student residence and HMO identifies that from 2005 onwards landlords and investors (both large student letting agents as well as parents buying a home for their student child) appeared to purchase properties in Kingfisher to convert into student a $\mathrm{HMO}$, thereby capitalising and perpetuating the latent demand for higher-quality student housing in the town. As one longstanding resident of Kingfisher reveals:

\footnotetext{
"They are modern, they are new, they have all got beautifully equipped kitchens and bathrooms ... the estate was built like that you see. You could move straight in, you didn't need to do anything at all. That's probably one reason why landlords started buying up because they didn't need a lot doing to them to change them over for students, they were all new and ready to go, whereas you'd need to do much more with the older Victorian [Golden Triangle] ones".
}

This led to the conspicuous transformation of Kingfisher with the rapid in-movement of students into the estate, evidenced by the total number of students residing in Kingfisher increasing by $37 \%$ between 2007 and 2012. By 2016 there were 60 student-let properties with over 300 students living in Kingfisher. In total, 277 house sale transactions took place in Kingfisher between 2001 and 2016. Our analysis indicates that of these transactions, 205 
involved a sale from an owner-occupier to a landlord/investor or a subsequent landlord/investor to landlord/investor sale (i.e. 'studentified sale'). Figure 2 reveals that before the economic recession of 2007, 139 property transactions took place between 20012006, with high levels of tenurial transformation from owner-occupation to private renting. What is particularly interesting here is the relatively high percentage increase in price (i.e. profit) between points of sale. There are three properties in Adam Dale, for example, selling for over $30 \%$ profit during this five-year period. This may suggest that, soon after the development of Kingfisher, landlords and investors quickly purchased family dwellings for conversion to student HMOs, especially the larger houses on the estate that could be converted to accommodate six or more students, and thus maximise rental income per dwelling. As one resident notes:

"These are big houses. Some of them have got five bedrooms, the tall ones, and several of them have been converted into six bedrooms. They've done that next door - it's a tandem double garage, a long double garage, and the back one they've turned into a downstairs room so you can get more students in".

During and after the economic recession, there appears to have been a general slowing down of the process of transformation, with 34 property transactions between 2007 and 2011, and, more recently, 32 property transactions between 2012 and 2016. Also evident is a lower percentage of property price inflation. Indeed, there is a reduction in the property prices of some dwellings (e.g. $25 \%$ loss in value). This may have been influenced by some owneroccupiers finding it increasingly difficult to sell their property in light of a low demand from other owner-occupiers who do not want to live in a student area, and increasing regulations 
imposed on the local authority for landlords to convert family dwellings to HMOs following the deployment of an Article 4 Direction in April 2012. As noted by one resident of Kingfisher:

"I know of two or three people who are residents here who would like to sell their house and move but they can't, they're trapped. They feel trapped from an economic view because if they did sell they can't get good money for them. It is a real Catch-22 because the people that want to move out want their houses to be able to be designated HMOs because then the landlords would buy the house and they'd get market value".

\section{THE DEMAND FOR HIGHER-QUALITY AND HIGHER-COST STUDENT HOUSING}

Focussing on the demand-side factors underpinning the movement of students into Kingfisher, this section draws upon findings from a student residential decision-making survey of undergraduates in Loughborough University halls of residence. A key finding is that Kingfisher's prime location on the door-step of the campus, coupled with the high-quality accommodation on offer, has seen it overtake the Golden Triangle to become the popular 'student area':

"I really wanted to live in Kingfisher. Everyone says the houses there are the best in Loughborough. I mean, they are new-builds, they've got huge bedrooms, bathrooms and kitchens, and it is right across the road from campus. And, well, it's just really cool to be able to say "I'm going to be living there next year", like everyone thinks it's a really cool place, you know" [Student \#96]. 
In line with Holton's (2015: 28) insightful study of student identities, students appear to "understand the importance of appropriating the right spaces", and the 'prestige' attached to these newer properties extends Chatterton's (2010) discussions on neoliberalisation. Kingfisher is ideally located in proximity to both the campus and town centre, but it has also become the 'place to be' due to its supply of high-quality accommodation, in comparison to other student neighbourhoods.

All students (100\%) who wish to reside in Kingfisher in the following academic year (September to August) searched to secure accommodation in December or even earlier in the academic year. This underlines its premium status and popularity. If quality accommodation in a prime location is required then students need to move quickly; if they are happy to accept a more basic standard then they can afford to be more relaxed about the accommodationseeking process due, in part, to the contention that there is an oversupply of approximately 2,000 bedspaces within the student accommodation market in Loughborough. Nearly half (45\%) of all students who waited until February to search for accommodation were intending to reside in Storer and Burleigh (i.e. the Golden Triangle).

\subsection{Facilities and amenities}

Importantly, findings from the survey show that students have increased expectations for higher-quality and higher-specification facilities and amenities in student housing. As Figure 3a shows, over $80 \%$ of students stated that broadband internet, TV facilities, washing facilities, double glazing and security were essential facilities they desired (and expected) in their accommodation. The student neighbourhood with the highest level of facilities and amenities included in the rental is found in the townhouse properties in Kingfisher (Figure 3b). The high- 
quality facilities and amenities provided in Kingfisher housing was a factor for the majority of students who will be moving to this area:

"It's all about the ensuite shower room. The house is really spacious when you get inside. The lounge and kitchen are really good. We are already looking forward to

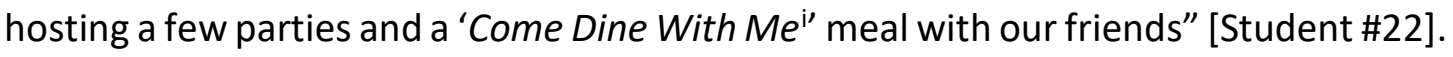

References to spacious living, ensuites, and dinner parties point to a new student lifestyle, with students' desire for a better standard of living whilst they are at university shaping the market. This, in part, relates to Holton and Riley's (2016) exploration of the role student accommodation plays in (re)developing students' identities, 'homemaking' and sense of place. Landlords and accommodation providers must respond to these new, stringent student demands, as well as to competition from on-campus halls of residence and town-centre PBSA. However, the facilities and amenities included in accommodation for students varies depending on the area. For example, whilst $81 \%$ of students who chose to reside in Kingfisher considered an ensuite 'essential', only $20 \%$ and $28 \%$ of students choosing Storer and Burleigh considered an ensuite to be 'essential'. As Figure 3b shows, students in Kingfisher are more likely to have large room sizes, car parking provision and American-style fridge freezers included in their student house than their Golden Triangle counterparts. Furthermore, Kingfisher out-scores Storer and Burleigh in 16 of the 18 facilities/amenities categories listed in the survey: 
“The terraces are quite small, and I don't think many of them have big rooms, ensuites, and things like that. If you compare a terrace to a house in Kingfisher, there is a big difference [in amenities/facilities]" [Student \#162].

The terraced housing in Storer and Burleigh lacks many of the higher-quality facilities, such as new kitchens, bathrooms with modern shower units, and car parking. Kinton et al. (2016) found that one of the key reasons processes of de-studentification are occurring in Storer is because the terraced houses are perceived to be poor-quality. Indeed, students argue that a lack of facilities, amenities and improvements to housing would impact negatively on the provider's success. In the same way that gentrifiers' lifestyles motivate their rejection of one area as they move to another, so the flow of students within university towns and cities away from the traditional terrace is similarly motivated:

"I didn't want to live in the Golden Triangle. We had a look at a couple of houses on Paget Street. I didn't like the terrace thing, and the fact that one of the rooms was basically downstairs on the front of the house. It didn't seem much like a home ... the kitchen was really small and so were a couple of the bedrooms" [Student \#234].

This reflects Holton's (2016: 59) contention that student accommodation is "more than simply somewhere to reside during term-time", arguing that the social and spatial configurations of shared student properties are complex. What is clear from the survey is that the experience of residing on campus during their first year shapes students' needs, preferences and expectations: 
"Living in halls for a year probably influenced my accommodation decision. You sort of look for a house or whatever that is the same really, that has nice rooms and stuff. You wouldn't go and live anywhere that is worse than campus" [Student \#28].

The growth of PBSA (in this case, new on-campus halls of residence) in raising the quality of student accommodation and recognising the lifestyles and demands of students is highly significant - what was once considered as optional or luxury is now becoming standard within the commodified and corporatised market. This drive to satisfy students' high demands can be observed in the incorporation of facilities such as plasma screen TVs, American-style fridge-freezers, double beds, dishwashers, washing machines and Sky TV packages into the student accommodation residential experience in Loughborough (see Figure 3 for a breakdown of students who have key facilities/amenities included in their accommodation). Students are expecting more amenities and services through their accommodation providers which all contribute to the overall experience of their accommodation. These student expectations need to be met or accommodation will be rejected. These expectations for higher-quality housing appear to be met in Kingfisher.

\subsection{Rental costs}

The demand and supply of relatively high-quality accommodation has a bearing on rental costs. In terms of the weekly inclusive rent students pay for accommodation, there is a distinct difference in rent based upon the number of and/or quality of facilities and amenities included in the housing. Students appear willing to pay a higher rent for newly-built, highquality accommodation, particularly PBSA (average 189 per week) and townhouses in 
Kingfisher (average $\mathrm{f} 85$ per week) compared to Storer and Burleigh terraced and semidetached housing, with an average all-inclusive rental cost of $£ 73$ per week.

There is a perception that better accommodation facilities and amenities usually mean that students will pay a higher rent. For example, $15 \%$ of students paying under $£ 69$ per week had an ensuite bathroom, compared to $60 \%$ of students paying $f 70-89$, and $98 \%$ of students paying $f 90+$. This contrasts with Christie et al.'s (2002: 219$)$ finding that "price was not always a clear reflection of the standard of housing, so that paying a higher rent did not necessarily improve conditions", presumably because the context has changed over time.

One important feature for over half of students is car parking and the availability of car parking space in proximity to their accommodation (see Munro and Livingston, 2011). This is more widely available in Kingfisher than in Storer and Burleigh (where parking permits are required). Again, rental costs tend to reflect the facilities and amenities on offer: students prepared to pay $\mathrm{f90+}$ for accommodation were more than twice as likely to get parking included (a designated space via a private driveway or an allocated space via a residents' parking permit from the council) in the rental package than those paying $f 89$ or less. These findings support the notion that students are willing to pay higher levels of weekly rent for a perceived better quality of living, as well as for space and modernity:

"I think that you pay more for more modern accommodation, for the size and space. You can get a really big house, more space, all the stuff you need if you are prepared to pay that little bit more" [Student \#170].

Whilst Christie et al. (2002: 219) found that conditions tolerated in HMOs were sometimes far from ideal and "linked both to low expectations about student housing and to students' 
relative inexperience in the housing market", the Loughborough experience is perceived - by both students and accommodation providers - to contradict this statement: students expect high-quality accommodation, a good service-led approach from operators, and ideally an allinclusive rent.

The more affluent student groups have the capacity to 'shop around', unencumbered by financial concerns, and there is a relationship between culture (facilities) and economy (cost) which creates a diversified student accommodation market. Whilst a small percentage of students want to increase their independence by paying bills, most students want allinclusive deals to minimise additional risk associated with fluctuating utility costs:

"All the bills are sorted for you in halls and it has just been so easy, so we wanted the same sort of deal next year in our house. You know exactly what you're getting that way" [Student \#127].

Interestingly, $75 \%$ of students living in Kingfisher had previously resided in the most expensive halls of residence on campus: catered, or newly-developed self-catering halls, all located in the 'student village' area of the campus. It appears that the sub-group of students most attracted to Kingfisher had been paying high fees for halls of residence, and are prepared to continue to pay for the best quality accommodation when they move off-campus. A distinction can be made here with students residing in Storer and Burleigh, with the majority (65\%) locating from some of the lower cost halls. Consequently, it may appear that these students have developed lower expectations for accommodation.

The low rental cost of the accommodation in the Golden Triangle area was a factor in the decision of some students to choose this area. Some of the cheapest student 
accommodation on the market is found in Storer and Burleigh and this attracts a sub-group of students on a more limited budget:

"I thought accommodation would be expensive but we saw one for $£ 45$ a week. I didn't want to pay loads and loads on accommodation ... it [the Golden Triangle] is probably one of the cheapest places, because you can get a house for, like, $f 65$ a week, with all the bills ... that's why I went for it in the end" [Student \#159].

Elsewhere we have argued how this polarised student accommodation market is evidently reflected spatially in the location that a student lives, and also socially with the emergence of two classes of student. One class of student is using their capital to move out of traditionally studentified wards (e.g. Storer, Burleigh) into high-quality, high rental, PBSA or housing estates (e.g. Kingfisher), and they are being replaced by another class of student who are moving into those de-studentifying areas. They too have capital, but whereas the first class of student use their capital to pay higher rents and can afford higher quality accommodation, the second class of student use their capital to drive down rental costs as much as then can (Kinton et al., 2016).

Interestingly, $60 \%$ of students surveyed will be paying less than the maximum weekly rent they had been prepared to pay to secure their first choice of accommodation. This reflects the fact that there is an oversupply of approximately 2,000 bedspaces within student accommodation in Loughborough, with landlords and agents prepared to offer lower rental rates to secure student tenants who could, potentially, find accommodation quite easily elsewhere (Kinton et al., 2016). In a time of oversupply of student accommodation, coupled with the economic downturn post-2008, students are realising they have bargaining power 
and are able to negotiate on rent. Student accommodation providers in Loughborough noted that they must let accommodation to students at a reduced rate or at a lower deal, as setting rents too high could lead to partial or empty property. One trend apparent through the survey is that financial deals, cost reductions, offers and incentives are occurring in the market, with landlords whose properties are regarded as the least attractive to students having to refurbish, drop rents, or target different rental groups. Many students can successfully negotiate reduced rents (or other deals) from providers.

However, no students who reside in Kingfisher negotiated a cost reduction, emphasising that this is one of the most popular areas of Loughborough, where students are willing to pay the full cost, and landlords have no need to resort to deals, reductions or offers to let their accommodation successfully. Storer is the area where students are most likely to negotiate:

“We negotiated some money off ... I just got a feeling that he hadn't really had much interest in it, that we were probably the first group that seemed quite interested ... he was really keen for us to sign up. So when we said, 'we are going to go away and have a think about it' he basically said straight away that he'd be willing to do it a little bit cheaper. So that sealed it for us, because the house has got everything we need really. Looking back at it now, he came across as a little bit desperate maybe, you know? Maybe if we had pushed it a bit more then we might have got him to drop the price even more" [Student \#57].

It is evident that students expect a high-quality overall university 'experience', and accommodation is a factor in terms of quality and whether it represents value for money. 
Students perceive themselves as consumers, for whom providers must cater to survive in a competitive market where service to students is paramount. It is students who appear to be the driving force in the market, and accommodation providers find that they must produce what prospective student tenants demand - or reduce the rent considerably - if they are not to lose out; nevertheless, the students' empowerment is 'bounded' by institutional practices, cultural norms and the consumer options on offer.

\section{DISCUSSION AND CONCLUSION}

Our main original contribution in this paper has been to demonstrate the need for a wider conceptualisation of studentification, to recognise that the processes of change are not inherently tied to physical downgrading of urban landscapes. We have presented original findings to illustrate the formation of a studentified neighbourhood, which emphasises the need for novel analyses of multiple datasets to pin down the production of student HMOs via the appropriation and conversion of family dwellings. Using the case study of Kingfisher we have identified a new frontier of studentification, which involves the production and consumption of exclusive student HMOs. We have shown that this is tied to the broader trend of the commodification of student accommodation and living that is crafted by institutional and commercial actors for students, whose residential decision-making practices are influenced by relatively high expectations of quality housing and services. This begs questions about stereotypical representations of studentification that are premised on the downgrading of the urban environment and the deterioration of the housing stock. It is evident that similar student geographies of higher-cost and higher-quality HMOs are emerging in other frontiers within university towns and cities, such as Canterbury (St. Stephens), Leeds (West Park), Manchester (Ancoats) and Nottingham (Wollaton). Overall, these new patterns of student 
geographies highlight the dynamism of local student housing markets in the UK, and the ways in which institutional actors are seeking to open up new markets to remain competitive, innovative, and maximise profits.

We argue that it is vitally important to advance understandings of these dynamics of the student housing market, given that wider urban geographies can be influenced in profound ways. To exemplify our argument, four key aspects of broader urban change can be highlighted.

First, the formation of new frontiers of studentification results in higher levels of displacement (or replacement) of settled residents from parts of towns and cities that have not previously been restructured by processes of studentification. This will lead to higher totals of displaced populations into other neighbourhoods, potentially influencing the wider supply of housing, and levels of affordability in towns and cities. It is plausible that rising demands for exclusively student HMOs in middle-class areas, and the conversion of middle class family dwellings to student housing, may accelerate and intensify the so-called 'broken housing market' by extricating family dwellings from the owner-occupied housing market. The dwindling supply of family dwellings for owner-occupation in some local housing markets may have the consequence of raising property prices and the movement of some social groups to other parts of towns and cities; reconfiguring the broader socio-economic and cultural geographies of university towns and cities. It is possible that this may spark emotive debates about the lack of affordable housing for both renting and owner-occupation, leading to housing shortages in some local areas. Significantly, the recommodification of family homes to exclusive student HMOs may also have substantial impacts on the wider social, economic and cultural fabric of the area, such as the reduction of the viability of certain local amenities 
(notably schools and retail services), as the groups who require these services are pushed out and away from these neighbourhoods.

Indeed, the conspicuous presence of a student population in exclusive HMOs is likely to have a significant influence on property prices. As we have seen, there is often an initial escalation in property prices due to rising demands (as landlords buy in to an increasingly desirable area), which can then be followed by a deflation in property prices (when there is student concentration and the adverse impacts of studentification encourages other established residents to sell-up). This process can result in some families becoming 'trapped' in these studentified neighbourhoods. Moreover, if a local authority seeks to regulate and control the production of HMOs on the grounds that they are detrimental to the local character of a neighbourhood, by deploying an Article 4 Direction, can lead to a decline in property prices. Key here is the need for landlords to obtain planning permission to undertake the conversion of a family dwelling (C3) to $\mathrm{HMO}$ (C4) (deemed a change in land use), and it is often assumed that planning permission will not be granted given an Article 4 has been deployed. Prospective sellers of family dwellings are therefore trapped as landlords do not seek to purchase a property, and there is a relatively low demand for owner occupation as the area gains a reputation as a student area, and a notoriety for the key signifiers of studentification, such as noise nuisance and lack of car parking.

Second, the over-supply of student housing in many towns and cities may trigger declining student populations and voids in student housing in less appealing student areas, leading to de-studentification (Kinton et al., 2016). What this emphasises are the wider interlinkages between expressions of more commodified forms of student housing, such as PBSA and exclusive $\mathrm{HMO}$, and the unfolding of de-studentification in more traditional student areas. Of course, one possible positive effect here may be the increased supply of rental 
accommodation for other social groups or the availability of affordable housing for families. Equally, if universities increase the intake of students, this may help to generate increased demand for student accommodation in some areas of towns and cities.

Third, the formation of enclaves of high-cost, exclusive student HMOs may lead to more polarised student accommodation markets, whereby those students priced out of increasingly expensive higher-quality student accommodation, or those prepared to compromise on their demands, may concentrate in lower-cost, downgraded neighbourhoods. Possible increasing socio spatial division within the student population means that students as a social group need to be more fully woven into wider debates about geographies of exclusion, immobility and the marginalisation, especially where other social groups (i.e. young professionals) increasingly compete with students in the private rented sector. These exclusionary patterns may also lead to increasing fragmentation of student experiences and lifestyles, as more differentiated local student housing markets engender new practices of territorialisation in academic term-time spaces. Exploring the emerging patterns of social interactions within and between groups of students, and delineated by different forms of student housing, provides an intriguing terrain for future research in student geographies.

Fourth, the formation of new enclaves of student housing in different parts of towns and cities means that some of the challenges of studentification (e.g. noise nuisance, car parking) may be ratcheted-up in both geographic scale and magnitude. This may have implications for the capacity of staffing and financial resources of local authorities, universities and other stakeholders. The design of new-build family dwellings often incorporates increased parking provision, improved waste/refuse management, and enhanced property upkeep by landlords, when compared to older terraced student HMOs. Although the downgrading signifiers of studentification are less prevalent in student areas tied to new-build housing, it is 
important to stress that many of the challenges tied to student lifestyles, such as noise nuisance from parties and returning taxis in the early hours of the morning, are evident, irrespective of the forms of the built environment. This means that concerns often articulated by settled populations about the detrimental effects of student lifestyles (i.e. noise nuisance) predominate across different geographical expressions of studentification.

To conclude, the empirical findings presented clearly have wider relevance for political, policy, institutional and community stakeholders in a range of urban settings, particularly in towns and cities where the issue of housing affordability is prominent on local political and policy agendas. Studentification is an on-going process of urban change that has important bearings on the shifting dynamics of broader urban geographies, and vice versa. It is essential therefore that processes of studentification are fully woven into national policy-orientated agendas that seek to foster cohesive communities.

\section{ACKNOWLEDGEMENTS}

We are grateful to two anonymous reviewers for very helpful recommendations, and to the Editor, Keith Richards, for his invaluble comments on the manuscript. We also want to thank the students who participated in the survey, local residents, and various local government planning and housing officers and councillors from Charnwood Borough Council. 


\section{REFERENCES}

Ackermann, A., Visser, G (2016). Studentification in Bloemfontein, South Africa. Bulletin of Geography Socio-economic Series, 31, 7-17.

Brooks, R. (2013). The social construction of young people within education policy: evidence from the UK's Coalition government. Journal of Youth Studies, 16, 318-333. 
Brooks, R., Byford, K., Sela, K. (2016). Students' unions, consumerism and the neo-liberal university. British Journal of Sociology of Education, 37, 1211-1228.

Chatterton, P. (2010). Commentary: the student city: an ongoing story of neoliberalism, gentrification, and commodification. Environment and Planning A, 42, 509-514.

Christie, H., Munro, M., Rettig, H. (2002). Accommodating students. Journal of Youth Studies, $5,209-235$.

Department for Business, Innovation and Skills (BIS). (2011). Higher education: students at the heart of the system. London: The Stationary Office.

Fabula, S., Boros, L., Kovács, Z., Horváth, D., Pál, V. (2017). Studentification, diversity and social cohesion in post-socialist Budapest. Hungarian Geographical Bulletin, 66, 157173.

Fincher, R., Shaw, K. (2009). The unintended segregation of transnational students in central Melbourne. Environment and Planning A, 41, 1884-1902.

Foote, NS. (2017). Beyond studentification in United States college towns: neighbourhood change in the knowledge nodes 1980-2010. Environment and Planning A, 49, 13411360.

Garmendia, M., Coronado, JM., Ureña, JM. (2012). University students sharing flats: when studentification becomes vertical. Urban Studies, 49, 1-18.

Ghani, ZA., Suleiman, N. (2017). Cash cow into the purse of Malaysian property investors: students housing investment. Path of Science, 3, 1013-1022.

He, S. (2015). Consuming urban living in 'villages in the city': Studentification in Guangzhou, China. Urban Studies, 52, 2849-2873.

Holdsworth, C., Brewis, G. (2014). Volunteering, choice and control: a case study of higher education student volunteering. Journal of Youth Studies, 17, 204-219. 
Holton, M. (2015). Adapting relationships with place: investigating the evolving place attachment and 'sense of place' of UK higher education students during a period of intense transition. Geoforum, 59, 21-29.

Holton, M. (2016). Living together in student accommodation: performances, boundaries and homemaking. Area, 48, 57-63.

Holton, M., Riley, M. (2013). Student geographies: exploring the diverse geographies of students and higher education. Geography Compass, 7, 61-74.

Holton, M., Riley, M. (2016). Student geographies and homemaking: personal belonging(s) and identities. Social \& Cultural Geography, 17, 623-645.

Hubbard, P. (2008). Regulating the social impacts of studentification: a Loughborough case study. Environment and Planning A, 40, 323-341.

Hubbard, P. (2009). Geographies of studentification and purpose-built student accommodation: leading separate lives?. Environment and Planning A, 41, 1903-1923.

Kenna, T. (2011). Studentification in Ireland? Analysing the impacts of student and student accommodation on Cork City. Irish Geography, 44, 191-213.

Kinton, C. (2013). Processes of studentification and de-studentification in Loughborough. PhD Thesis. Retrieved from https://dspace.lboro.ac.uk/dspacejspui/bitstream/2134/12668/3/Thesis-2013-Kinton.pdf

Kinton, C., Smith, DP., Harrison, J. (2016). De-studentification: emptying of housing and neighbourhoods of student populations. Environment and Planning A, 48, 1617-1635.

Moos, M., Revington, N., Wilkin, T., Andrey, J. (2018) The knowledge economy city: gentrification, studentification and youthification, and their connections to universities. Urban Studies, https://doi.org/10.1177/0042098017745235 
Munro, M., Livingston, M. (2011). Student impacts on urban neighbourhoods: policy approaches, discourses and dilemmas. Urban Studies, 49, 1679-1694.

Nakazawa, T. (2017). Expanding the scope of studentification studies. Geography Compass, DOI: 10.111/gec3.12300.

Prodigy Living. (2016, January 20). Chapter Spitalfields, London: Belong to a vibrant, innovative and diverse community with the city on your doorstep. Retreived from http://www.chapter-living.com//properties/spitalfields.

Ruming, K., Dowling, R. (2017). PhD students' housing experiences in suburban Sydney, Australia. Journal of Housing and the Built Environment, DOI: 10.1007/s10901-0179548-3.

Sage, J., Smith, DP., Hubbard, P. (2012a). The rapidity of studentification and population change: there goes the (student)hood. Population, Space and Place, 18, 597-613.

Sage, J., Smith, DP., Hubbard, P. (2012b). The diverse geographies of studentification: living alongside people not like us. Housing Studies, 27, 1057-1078.

Sage, J., Smith, DP., Hubbard, P. (2013). New-build studentification: a panacea for balanced communities?. Urban Studies, 50, 2623-2641.

Smith, DP. (2005). Studentification: the gentrification factory?. In R. Atkinson and G. Bridge (eds.) Gentrification in a Global Context, Routledge: London, 72-89.

Smith, DP. (2008). The politics of studentification and (un)balanced' urban populations: lessons for gentrification and sustainable communities?. Urban Studies, 45, 25412564.

Smith, DP., Holt, L. (2007). Studentification and 'apprentice' gentrifiers within Britain's provincial towns and cities: extending the meaning of gentrification. Environmental and Planning A, 39, 142-161. 
Smith, DP., Hubbard, P. (2014). The segregation of educated youth and dynamic geographies of studentification. Area, 46, 92-100.

Zhao, W., Zou, Y. (2017). Un-gating the gated community: the spatial restructuring of a resettlement neighbourhood in Nanjing. Cities, 62, 78-87. 
FIGURE 1: The geographies of HMOs on the Kingfisher Estate (2016). Includes a contextual map inset to show Kingfisher's location within Loughborough and the proportion of the student population that reside in key locations in the town.

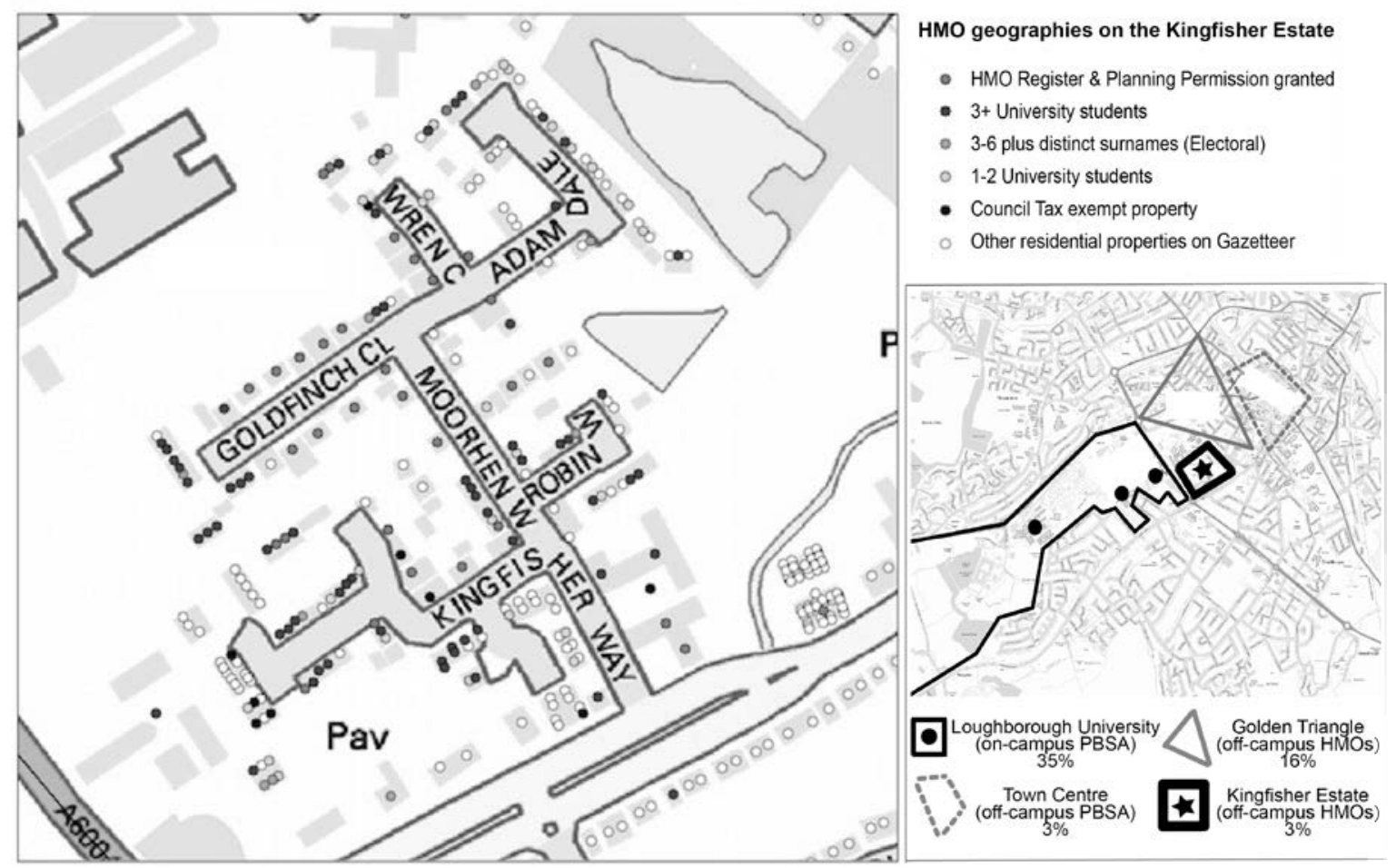


FIGURE 2: Property transactions, subsequent sales and percentage value change of housing classed as 'studentified' in Kingfisher 2001-2016.

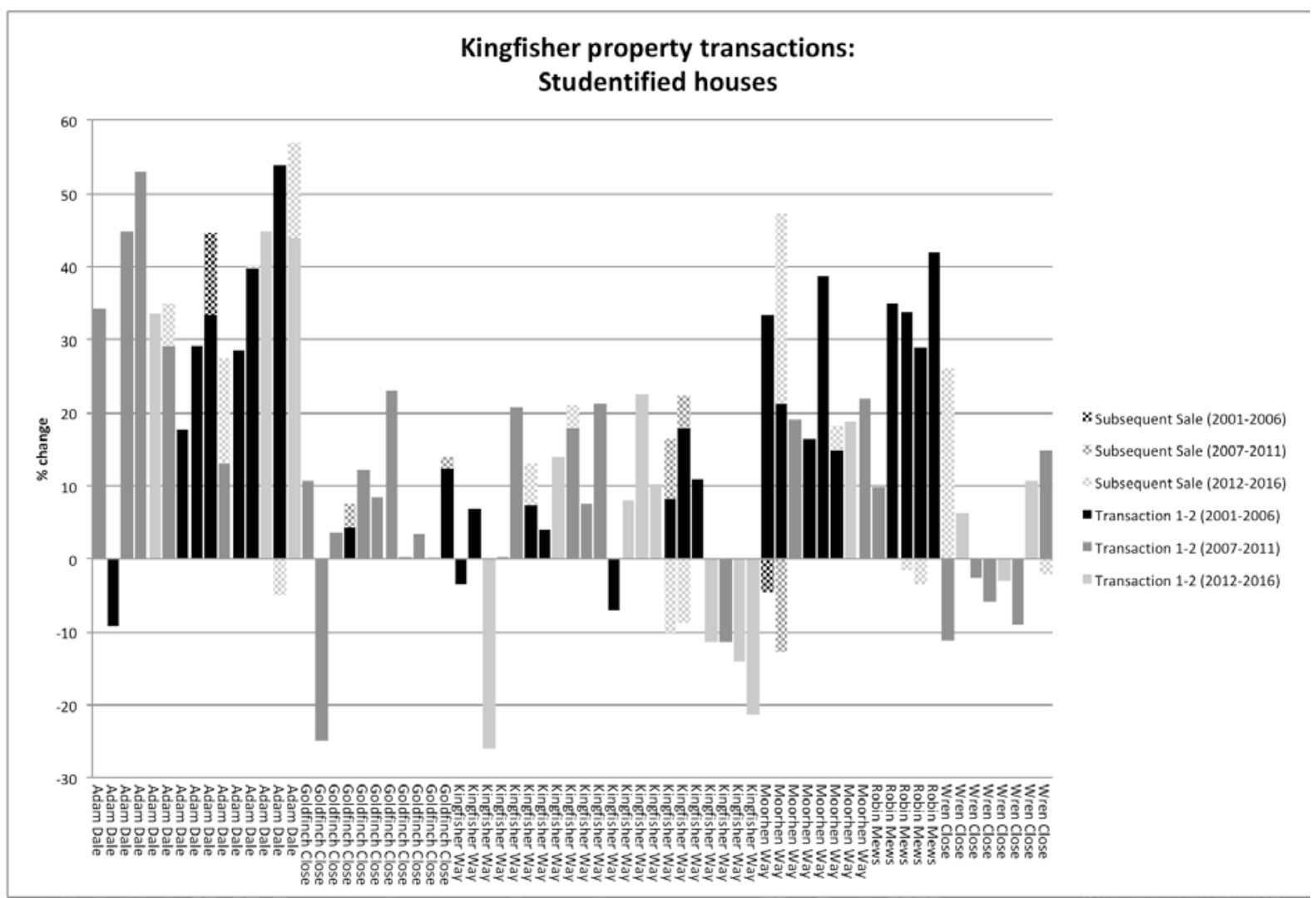


FIGURE 3: Facilities and amenities students consider either 'essential', 'desirable', or 'not important' in their accommodation decision and the facilities and amenities (Figure 3a) included in student accommodation in a. Storer; b. Burleigh; and, c. Kingfisher (Figure 3b).

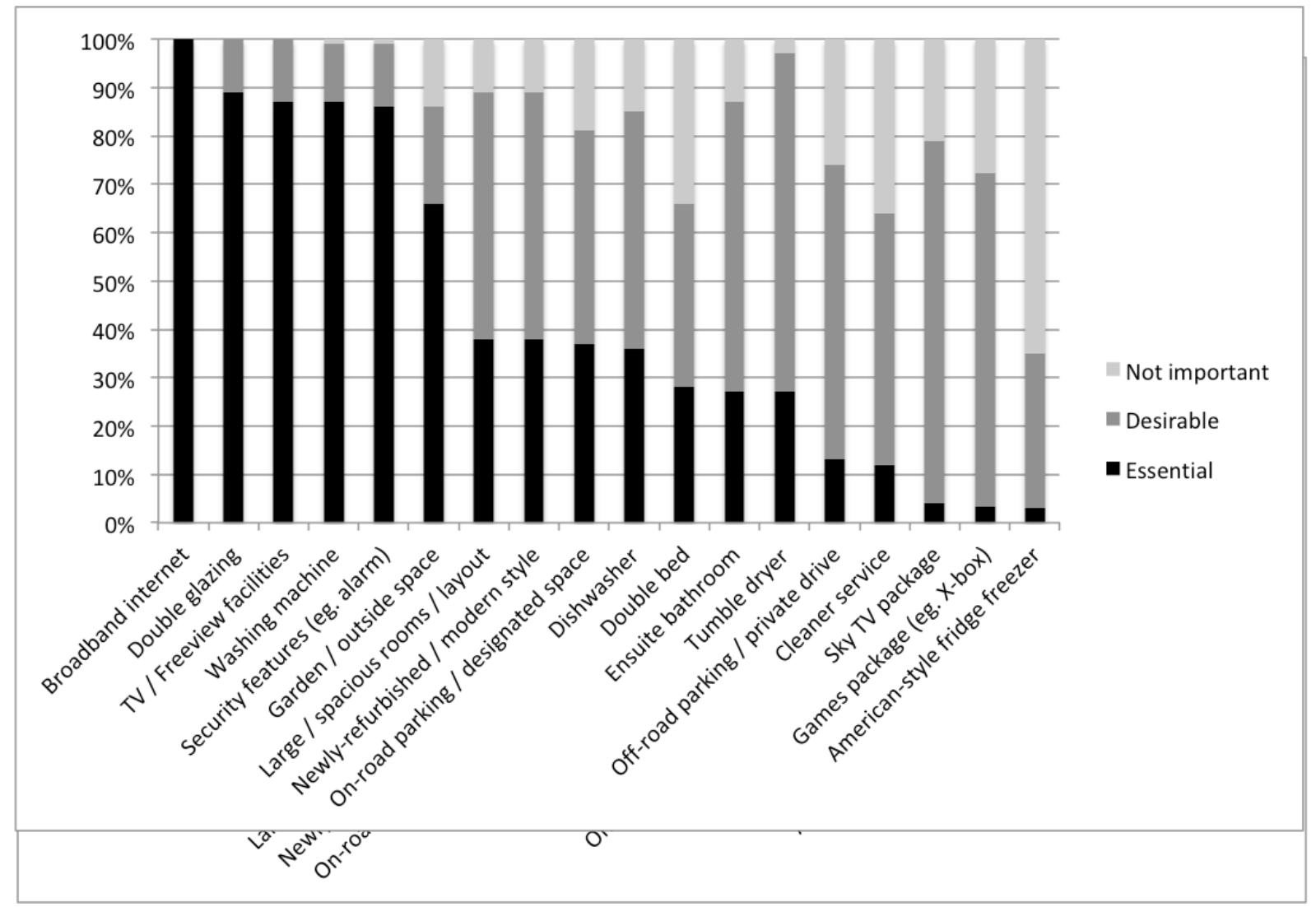

' 'Come Dine With Me' is a popular cooking television programme in the UK where contestants compete against each other hosting dinner parties in their own home. Contestants rate fellow competitors on their hosting and cooking performance in order to be crowned 'best host' and to win a cash prize. 